\title{
Immunochromatography and laboratory serologies: an evaluation of immunodiagnoses in prenatal care
}

\author{
Imunocromatográficos e sorologias laboratoriais: avaliação de imunodiagnósticos no cuidado pré-natal \\ Inmunocromatográficos y serologías laboratoriales: evaluación de inmunodiagnósticos en el cuidado prenatal
}

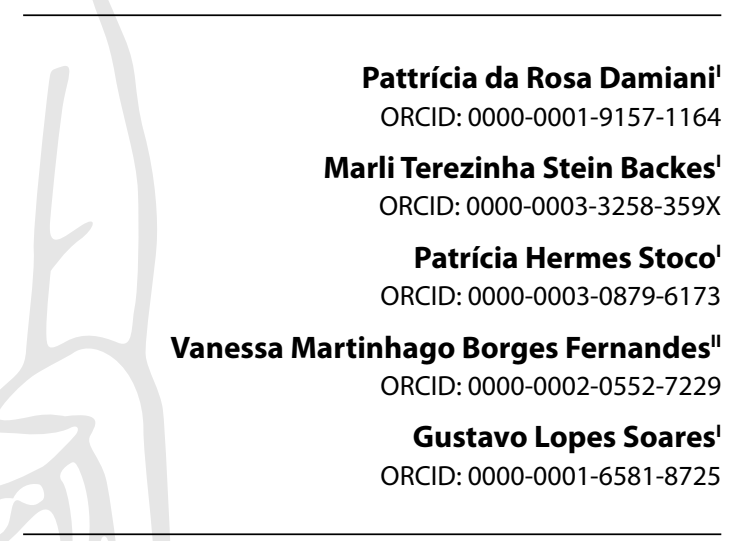

'Universidade Federal de Santa Catarina. Florianópolis, Santa Catarina, Brazil.

"Universidade do Sul de Santa Catarina. Florianópolis, Santa Catarina, Brazil.

How to cite this article:

Damiani PR, Backes MTS, Stoco PH, Fernandes VMB,

Soares GL. Affinity chromatography and laboratory serologies: an evaluation of immunodiagnoses in prenatal care. Rev Bras Enferm. 2021;74(2):e20200877. https://doi.org/10.1590/0034-7167-2020-0877

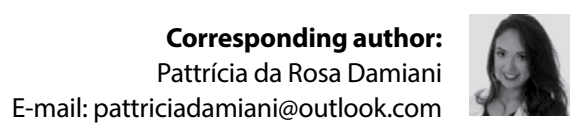

EDITOR IN CHIEF: Antonio José de Almeida Filho ASSOCIATE EDITOR: Fátima Helena Espírito Santo

Submission: $08-03-2020$

Approval: 11-13-2020

\begin{abstract}
Objectives: to describe the use of affinity chromatographies and laboratory serologies in the evaluation of immunodiagnoses during prenatal. Methods: quantitative study, characterized as a descriptive observational research. Data was collected from the records of 46 pregnant women who were in prenatal follow up in the Primary Health Care in a capital in the South of Brazil. The data found was codified and analyzed using descriptive statistics. Results: a mean of 43.1 days was found to take place between the request of laboratory serology and the evaluation by a professional. It was also found that $21.7 \%$ of pregnant women did not collect the serologies requested during the first prenatal consultation, and that the affinity chromatographies were only applied in $10.8 \%$ of the participants. Conclusions: in spite of the studies for the improvement of prenatal consultations, for the provision of new technologies and for the permanent education offered to the professionals, there are still questions that make the actual implementation of affinity chromatographies more difficult.

Descriptors: Primary Health Care; Prenatal Care; Chromatography, Affinity; Immunologic Tests; Biomedical Technology.
\end{abstract}

\section{RESUMO}

Objetivos: descrever a utilização dos testes imunocromatográficos e das sorologias laboratoriais na avaliação de imunodiagnósticos durante o pré-natal. Métodos: estudo de abordagem quantitativa, caracterizado como uma pesquisa observacional do tipo descritiva. Foram coletados dados dos prontuários de 46 gestantes que realizam acompanhamento pré-natal na Atenção Primária à Saúde de uma capital do Sul do Brasil. Os dados obtidos tiveram seu conteúdo codificado e analisados mediante estatística descritiva. Resultados: foi identificada uma média de 43,1 dias desde a solicitação das sorologias laboratoriais até a avalição profissional. Nesse sentido, também foi verificado que $21,7 \%$ das gestantes não coletaram as sorologias solicitadas durante a primeira consulta pré-natal e que foram aplicados testes imunocromatográficos em apenas $10,8 \%$ dos participantes. Conclusões: apesar dos estudos para o aprimoramento da consulta pré-natal, do fornecimento de novas tecnologias e da educação permanente ofertada aos profissionais, ainda persistem questões que dificultam a concreta implementação dos testes imunocromatográficos.

Descritores: Atenção Primária à Saúde; Cuidado Pré-Natal; Imunocromatografia; Imunodiagnóstico; Tecnologias em Saúde.

\section{RESUMEN}

Objetivos: describir la utilización de los inmunocromatográficos y de las serologías laboratoriales en la evaluación de inmunodiagnósticos durante el prenatal. Métodos: estudio de abordaje cuantitativo, caracterizado como una investigación observacional del tipo descriptiva. Recogidos datos de los prontuarios de 46 gestantes que realizan acompañamiento prenatal en la Atención Primaria de Salud del Sur de Brasil. Datos obtenidos tuvieron su contenido codificado y analizados mediante estadística descriptiva. Resultados: identificada una mediana de 43,1 días desde la solicitud de las serologías laboratoriales hasta la evaluación profesional. Así, también se verificó que $21,7 \%$ de las gestantes no recogieron las serologías solicitadas durante la primera consulta prenatal y que aplicaron inmunocromatográficos en solo 10,8\% de los participantes. Conclusiones: sin embargo los estudios para perfeccionamiento de consulta prenatal, provisión de nuevas tecnologías y educación permanente ofertada a los profesionales, aún persisten cuestiones que dificultan la concreta implementación de inmunocromatográficos. Descriptores: Atención Primaria de Salud; Cuidado Prenatal; Inmunocromatografías; Inmunodiagnóstico; Tecnologías en Salud. 


\section{INTRODUCTION}

Public policies for woman and child health care have been built according to social demands and scientific-technological advances. Considering this logic, prenatal care goes through a path of advances in the search for quality and safety for the mother-child dyad, instituting actions related to prevention, diagnostic, and to the clinical management of potential obstetric complications or existing pathologies, guaranteeing an early treatment and a safe birth to the newborn ${ }^{(1-3)}$.

With this in mind, the Ministry of Health prescribes that immunodiagnostic tests (laboratory serologies or immunochromatographies) should take place in the first three trimesters of pregnancy. The first prenatal consultation is when the nurse or physician responsible carries out the first and most thorough screening for pathologies, seeking pathologies that cause health damage to the fetal development or to the newborn. These are: the human immunodeficiency virus (HIV), syphilis, toxoplasmosis, hepatitis $B$, and hepatitis $C^{(4)}$.

Considering the clinical importance of an early detection of potential risks for the pregnancy, the immunochromatography (fast test) is the diagnostic method prescribed for the first prenatal consultation, since it is an exam that is easy to apply and can be carried out using the blood sample from a single immunologic strip, showing its results in approximately 30 minutes ${ }^{(5)}$. Serological laboratory exams, in turn, require specific laboratory equipment, hours or days to show their results, and data collection through venipuncture in environments other than the health centers ${ }^{(6)}$.

Naturally, when the methods are compared, the application of the immunochromatography, a much more accessible technology, is much more adequate to deal with the follow up of the immunologic situation of pregnant women, since the test is guaranteed to be extremely sensitive and specific, in addition to the clear advantages of its availability to be carried out early, allowing for data interpretation and to start actions to manage any situation ${ }^{(7)}$.

The adoption of these technologies to follow up obstetric nursing and medicine, as well as the updating of public policies targeted at the health of women and of newborns that actualize the right to access the early diagnostic of infectious pregnancy pathologies, are still, however, not strategies capable of responding to the challenging of prenatal care settings of the country ${ }^{(8)}$.

According to national data, the research "Nascer no Brasil" ("Being born in Brazil"), carried out from 2011 to 2012, shows that $22.8 \%$ of neonate deaths due to congenital malformations may be related to the vertical transmission of pathogens ${ }^{(9)}$. In pregnant women with hepatitis $B$, the vertical transmission takes place from $70 \%$ to $90 \%$ of cases, with estimates that these children are nearly 200 times more likely to develop hepatocellular carcinomas, which shows how important an early diagnoses is in the prenatal(9). Similarly, another study has found a high rate of HIV detection in pregnant women in the last 10 years, showing a $38.1 \%$ increase in the country ${ }^{(8)}$.

The increase in the detection of pathologies does not demonstrate objectively that there have been failures in the diagnostic process of the first prenatal consultation. However, overviews from recent studies have shown that these detections take place late for obstetric follow up. In a data analysis of the city of Florianópolis, the syphilis diagnosis in pregnant women during birth, for example, grew from $28.4 \%$ in 2018 to $42 \%$ in 2019 . In the same city and year, $26 \%$ of cases of this pathology found in prenatal consultations were only detected in the third trimester of pregnancy ${ }^{(8-11)}$.

This setting suggests that, in spite of the availability of immunodiagnoses as technologies to be applied in clinic to promptly diagnose and treat infections in the period of pregnancy, the health problems continue to grow due to the late screening of pregnant women ${ }^{(1)}$. To understand this phenomenon, two studies are required to describe the clinical use of immunochromatography and laboratory serologies, to search for knowledge about the factors that lead to delays in the early identification and in the reduction of the vertical transmission rates of HIV, syphilis, and of viral hepatites, also aiding in the diminution of avoidable child and mother deaths.

This article is the result of the undergraduate thesis entitled "Immunochromatography technology performed by Nurses in prenatal care: application and evaluation"(1).

\section{OBJECTIVES}

To describe the use of immunochromatographies and laboratory serologies in the evaluation of immunodiagnoses during the prenatal.

\section{METHODS}

\section{Ethical aspects}

Ethical aspects regarding this research were respected, according to Resolution No. 466/12 from the National Council of Health and approved by the Human Research Ethics Committee ${ }^{(1)}$.

\section{Design, period and place of study}

This is a descriptive, quantitative, and exploratory research, which followed the recommendations of the Strengthening the Reporting of Observational Studies in Epidemiology (STROBE). The research was carried out in Primary Health Care in a capital of the Southern Region of Brazil. Four health centers were selected, covering all health districts in that municipality. Data collection was carried out in September and October $2018^{(1)}$.

\section{Population, criteria of inclusion and exclusion}

The population of the study consisted of 46 pregnant women registered in the Single Health System and who were undergoing prenatal care in the collection scenarios. The sample was of the non-probabilistic type, considering a population of 147 pregnant women and with a confidence level of $90 \%{ }^{(1)}$.

The following inclusion criteria were considered: pregnant women who started the prenatal and followed up with it only in public health services, in any gestational age, and who were above 18 years of age ${ }^{(1)}$. Criteria of exclusion were: pregnant women who, before consultation, had already been through serological exams 
of the pathologies investigated, having determined a diagnosis and/or started the treatment ${ }^{(1)}$.

\section{Study protocol}

At the start of data collection, the pregnant women were addressed in groups, in the waiting room. The research was presented to them and they were invited to participate in the study and to provide access to the electronic records they had with the city ${ }^{(1)}$. After authorization, data were collected from the pregnant women's medical records using a research instrument, in order to collect data regarding obstetric history, age, gestational age, serological tests and clinical conduct of health professionals during prenatal care. This instrument was elaborated by the authors and validated through a pilot test carried out with four pregnant women before data collection started ${ }^{(1)}$.

\section{Analysis of results and statistics}

The data obtained was codified and organized in an electronic spreadsheet. Later, it was analyzed using statistical treatment, evaluating the absolute frequency, the relative frequency, means, bivariate analyses, and the Kruskal-Wallis test. The results are presented below in tables and figures.

\section{RESULTS}

The sample of the study was made up by 46 pregnant women, with a mean age of 27.36 years. It stood out that 41 (89.1\%) participants started their prenatal in the 1st trimester of pregnancy, and 35 (76\%) were assisted, in their first consultations, by nurses $(\text { Table } 1)^{(1)}$.

Table 1 - Distribution of sociodemographic variables of pregnant women in prenatal care $(\mathrm{N}=46)$, Florianópolis, Santa Catarina, Brazil, 2018

\begin{tabular}{lcc}
\hline Pregnant women and the prenatal consultation & $\mathbf{n}$ & $\%$ \\
\hline Age of the pregnant woman & & \\
18 to 28 years & 25 & 54.3 \\
29 to 37 years & 21 & 45.6 \\
Gestational history & & \\
$\quad$ Primigravida & 23 & 50 \\
$\quad$ Multigravida & 23 & 50 \\
Trimester of pregnancy at the first prenatal consultation & & \\
1st trimester (1-14 weeks) & 41 & 89.1 \\
2nd trimester (15-27 weeks) & 4 & 8.6 \\
3rd trimester (>28 weeks) & 1 & 2.1 \\
Trimester of pregnancy at the last prenatal consultation & & \\
1st trimester (1-14 weeks) & 5 & 10.8 \\
2nd trimester (15-27 weeks) & 15 & 32.6 \\
3rd trimester (>28 weeks) & 26 & 56.5 \\
Professional that performed the first prenatal consultation & & \\
$\quad$ Nurse & 35 & 76 \\
$\quad$ Physician & 11 & 24 \\
Anamnesis and physical exam in the prenatal consultation & & \\
$\quad$ No changes & 44 & 96 \\
$\quad$ Risk signs for infectious pathologies & 2 & 4 \\
\hline
\end{tabular}

Regarding the anamnesis and the physical examinations, carried out in the prenatal consultation, $4 \%$ of pregnant women showed risk signs for infectious pathologies. However, the immunochromatography was not used during the prenatal follow up ${ }^{(1)}$.

When comparing the mean of the number of days from the request of immunodiagnostic exams and the evaluation of the health professionals, a strong correlation was found between the variables. The mean was 41.1 for laboratory serologies, and 1.2 days for immunochromatographies (Figure 1). The percentage of these exams that was carried out was found using the KruskalWallis test to verify whether the variable "time from the request of the exam to the evaluation of the professional" $(p<0.0003)$ was significantly different between the groups "laboratory serology" and "immunochromatography".

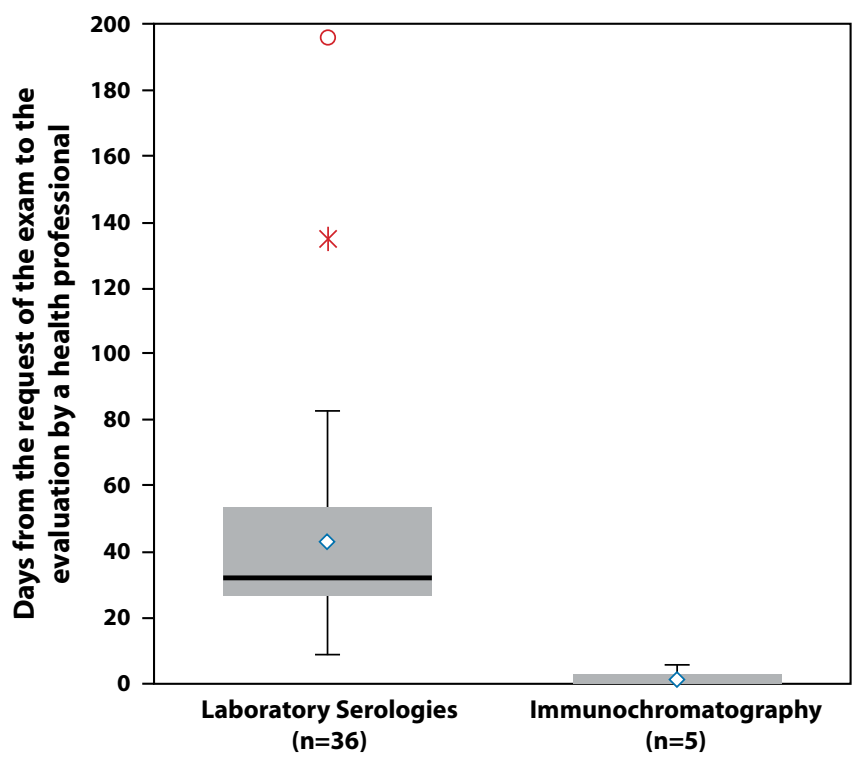

Figure 1 - Box graph relating the mean of days from the request of immunodiagnostic tests until the evaluation by a health professional in the prenatal consultation, Florianópolis, Santa Catarina, Brazil, 2018

There was a long period between the request of laboratory serologies and the collection of material for the exams and, later, from the collection to the evaluation, since the number of days waiting had a mean of 22.1 and 21 days, respectively ${ }^{(1)}$. In addition to these long periods, from the 46 requests for serologies, $10(21.7 \%)$ were not collected. It should be highlighted that there was, according to electronic records, a mean period of 73.6 days from the first request to the last consultation, when these pregnant women had yet to collect for the exams ${ }^{(1)}$.

Regarding the records of the professionals, about their actions regarding the results of the immunodiagnostic exams (Table 2$)^{(1)}$, it was found that, in the laboratory exams, from the 36 cases in which this evaluation took place, 18 (50\%) did not have records related to the clinical management of the results in the records of the pregnant women. On the other hand, all tests were registered by the professionals in the records of the study participants, and professionals complied with the protocols of the city by offering pre- and post- fast test counseling.

According to the results, it was found that the professionals that requested and applied immunochromatography tests the most were the nurses, with $4(80 \%)$, while only one physician (20\%) carried out this procedure. 
Table 2 - Percentage distribution of the actions of the professionals in the use of the immunodiagnostic during the prenatal follow up, Florianópolis, Santa Catarina, Brazil, 2018

\begin{tabular}{|c|c|c|}
\hline Evaluation of the prenatal immunodiagnoses & $\mathbf{n}$ & $\%$ \\
\hline \multicolumn{3}{|l|}{ Laboratory serologies $(n=36)$} \\
\hline \multicolumn{3}{|l|}{ Professional that evaluated the results of laboratory serologies } \\
\hline Nurse & 19 & 52.7 \\
\hline Physician & 17 & 47.2 \\
\hline \multicolumn{3}{|l|}{ Clinical conduct after the results of laboratory serologies } \\
\hline No records & 18 & 50 \\
\hline Guidance based on results & 13 & 36.1 \\
\hline Guidance and general results based on results, presenting lg-G non-reactive toxoplasmosis. & 4 & 11.1 \\
\hline Guidance and general results based on results, presenting lg-G non-reactive toxoplasmosis and RUBEOLA. & 1 & 2.7 \\
\hline \multicolumn{3}{|l|}{ Immunochromatography $(\mathrm{n}=5)$} \\
\hline \multicolumn{3}{|l|}{ Professional that evaluated the results of the immunochromatography } \\
\hline Nurse & 4 & 80 \\
\hline Physician & 1 & 20 \\
\hline \multicolumn{3}{|l|}{ Clinical conduct of professionals after the results of the immunochromatographies } \\
\hline No records & 0 & 0 \\
\hline Guidance based on results & 5 & 100 \\
\hline Guidance pre- and post-test & 5 & 100 \\
\hline
\end{tabular}

\section{DISCUSSION}

The health levels of the mother-child dyad are connected to the quality of the prenatal care, a form of care that, in turn, is directly correlated to an adequate assistance in the periods of pregnancy and puerperium, which, above all, impacts the incidence and prevalence of the infectious pathologies and their vertical transmission, congenital malformations and the consequent mother-child morbimortality ${ }^{(1,12-13)}$. However, this process of care presents many challenges. One of them is the effective early detection of pathologies that put the pregnancy in risk, through the application of immunodiagnostic exams in the first prenatal consultation of pregnant women, which is the focus of the investigation carried out here.

It stands out that the cases in which the laboratory serology requested is not performed in the first trimester of pregnancy represents a considerably high number within the sample analyzed. The time spent from the request of the exams to the evaluation of results was also significant, and the process to guarantee quality and identify risks for the prenatal follow up was slow.

Studies published in $2018^{(13-14)}$, and another in $2020^{(15)}$, corroborate the finding that there is absenteeism with regard of laboratory serologies, also showing low rates of people who undergo the exams prescribed by the Ministry of Health. Therefore, the results of this investigation are in accordance with data from the other studies surveyed. However, they also raise questions about inadequate prenatal follow ups, from the point of view of the adequate adoption of the immunodiagnostic test that should be requested timely, during the first prenatal consultation.

The vertical transmission and unfavorable outcomes to the pregnancy are proportional to the inadequate management of cases and to the losses associated with the diagnosis and to the early beginning of treatment for infectious pathologies ${ }^{(16-17)}$.Considering that, the data is worrisome since it shows that, when confronted with signs of risk for infectious diseases in the gynecological and obstetric clinical exam, found by the professional responsible for the exam, the pregnant women were not advised and/or directed to undergo early serological examinations, even when diagnostic methods were available, such as the immunochromatography, which could bring these results in a short period of time.

Rede Cegonha (the "Stork Network") prescribes that the immunochromatography tests should be the method used to screen for infectious pathologies during the first prenatal consultations, as opposed to the laboratory serologies ${ }^{(1,18)}$, since their benefit for health monitoring are justified. Then, a worrisome factor is to identify that, although pregnant women who participate in the study went to prenatal consultations with trained professionals, nurses and physicians, they did not choose the fastest diagnostic method, an action which is not favorable for an agile interpretation of results.

On the other hand, a study from 2018, carried out in Rio de Janeiro, showed that there was an increase in this testing method in the maternity during the hospitalization for childbirth, due to the lack of knowledge about the serological status and the need of immediate results ${ }^{(1,7)}$. Another work published in 2020 evaluated the prevention of the vertical transmission of HIV in the hospital context, and both the outcomes found a correlation with interventions that were not timely or adequate to be used in the primary care for pregnant women ${ }^{(19)}$.

Furthermore, a study carried out in Fortaleza found that there is a high number of pregnant women with no related notes in their prenatal follow up records and form $\mathrm{s}^{(1,3)}$. This research is connected to the findings of this study, since it observed that half of the professionals also did not describe, in the progression records of the patients, information related to their laboratory serology that would be useful for their clinical management, there being only records of the requests for exams, and of the dates in which the collection for these exams took place and in which their results were issued, at least with regard to information integrated into municipal network.

Considering the ineffective follow up of laboratory serologies, questions are raised about the reasons that lead Primary Health Care professionals not to execute immunochromatographies during the following consultations of pregnant women with no serological results, in the cases they were not present for the exam, which delays the results even longer ${ }^{(1)}$. 
These factors may be related to the high demand and to the management of the time of assistance, as well as to the lack of understanding about the reduction of risks that could be achieved by taking advantage of the presence of the pregnant woman who was absent in the previous exam for a fast and timely test in the office (instead of referring them again to a serological exam or sending them for an external collection). Other related factors are the deficit of professionals, with the consequent diminution of attention coverage and of the possibility of forming a bond.

Corroborating the results of this study, the South of Brazil is a region of the country in which the immunochromatography tests are still being implemented, and there are obstacles relative to the insufficiency of infrastructure, human resources, and difficulties for the construction of work flow that aid in the service provided ${ }^{(1,20)}$. The increase in the cases of congenital syphilis is a strong and current issue in the region, associated to late diagnoses and deficits in the clinical management of these pregnant women and their partners ${ }^{(17)}$. The slow implementation of the rapid testing validates delays in the diagnosis and in the treatment of infectious of pathologies that negatively impact the health of women and their children, as well as collective health.

Similarly, an ecological research carried out in the Primary Health Care in Brazilian cities with more than 20 thousand inhabitants have found that the cities in which there was a reduction in the congenital syphilis cases had the family health teams that offered the higher amounts of immunochromatography tests ${ }^{(21)}$. This study, despite having analyzed only gestational syphilis, unveils a determining factor, which is the importance of carrying out rapid tests in the prenatal context, showing how the low adherence to this diagnostic technology, as shown by this research, weakens the quality of follow up and leads to unfavorable outcomes.

Another highlight is that, despite the low adherence found for immunochromatography tests, most professionals who used the technology were nurses. It can be found that the professionals from this category are the ones who are in the best position to apply this test the Primary Health Care, thus being essential members to completely implant the technology in the prenatal ${ }^{(1,20,22)}$.

Considering this, it became clear that the prenatal has its shortcomings, among which the abstention of the pregnant women that should undergo laboratory serologies, opening the door to cases of vertical transmission of mother-child complications ${ }^{(1,20,22)}$. This factor needs to be further investigated, through researches that seek to identify the reasons for the adherence or lack thereof of pregnant women to the exam. Reasons may be found in the distance from the lab, the lack of bonds in another service, and socioeconomic aspects ${ }^{(1)}$.

The low use of technological resources by health professionals, contributes to the decrease in the quality of prenatal care, mainly by not promoting an early detection of infectious pathologies during pregnancy in a timely manner; preventing early treatment and clinical recovery, which compromises the resolution of actions and contributes to insufficient quality prenatal care ${ }^{(1)}$.

In this way, it is important to highlight that the use of technological resources, in relation to immunodiagnostics, during pregnancy is not characterized as an exclusive duty of health professionals, who must make the request and/or the performance of exams and the registration of results, whether immunochromatographic or laboratory. This approach also refers to the users themselves, who are responsible for their own health and their concepts, because, in this context, even with the availability of immunodiagnostics in the SUS, there is a need for pregnant women to empower themselves in the face of this responsibility and be willing to perform exams during prenatal care.

\section{Study limitations}

A limitation of this study is the fact that the sample was nonprobabilistic and there was a limited number of fields for data collection, which makes it impossible to generalize the findings for the entire city.

\section{Contributions to the fields of Nursing, Health or Public Policy}

The study's contribution is in assessing the clinical utility of immunochromatography tests and demonstrating the importance of their application in the setting of prenatal care, however the presence of numerous difficulties was identified for their complete adherence by professionals in Primary Health Care. This evidence helps to minimize the quality provided during prenatal care, by not giving priority to the application of diagnostic technologies that provide the diagnosis and treatment that are more effective for the health of the mother-child binomial.

\section{CONCLUSIONS}

This study made it possible to identify the existence of low performance of laboratory immunodiagnostic exams by pregnant women, also minimizing the screening and early detection of infectious pathologies. In the same sense, there is also a low adherence by health professionals to apply immunochromatography tests during prenatal care, even in the face of several cases of abstaining from these tests and pregnant women who showed signs of risk for these diseases. Despite this, there is an understanding that the nurse keeps constantly improving and updating his clinical practice, being the professional who got more prominence for including immunochromatography during the prenatal consultation.

The low applicability of immunodiagnostic tests, facilitates a direction to increase the levels of vertical transmission, and to avoidable perinatal and child deaths, diagnosing several weaknesses in the assistance provided to obstetric and neonatal health.

\section{REFERENCES}

1. Damiani PR. Tecnologia de imunocromatográficos realizada por enfermeiros no acompanhamento pré-natal: aplicação e avaliação [Dissertação] [Internet]. Florianópolis: Universidade Federal de Santa Catarina; 2018 [cited 2020 Nov 5]. 83 p. Available from: https:// repositorio.ufsc.br/handle/123456789/191346 
2. Livramento DVP, Backes MTS, Damiani PR, Castillo LDR. Perceptions of pregnant women about prenatal care in primary health care. Rev Gaúcha Enfem. 2019;40(1):1-9. https://doi.org/10.1590/1983-1447.2019.20180211

3. Silva JR, Oliveira MBT, Santos FDRP, Santos Neto M, Ferreira AGN, Santos FS. The quality indicators of high-risk prenatal care in a public maternity hospital. Rev Bras Cienc Saúde. 2018;22(2):109-16. https://doi.org/10.4034/rbcs.2018.22.02.03

4. Balsells MMD, Oliveira TMF, Bernardo EBR, Aquino PS, Damasceno AKC, Castro RCMB, et al. Evaluation of prenatal care process for habitualrisk pregnant women. Acta Paul Enferm. 2018;31(3):247-54. https://doi.org/10.1590/1982-0194201800036

5. Punt J, Stranford S, Jones P, Owen JA. Kuby Immunology. 8. ed. New York: W.H.Freeman \& Co Ltd; 2018.

6. Nicoll D, Lu CM, McPhee SJ. Manual de exames diagnósticos. 6 ed. Porto Alegre: AMGH e Artmed; 2014.

7. Wang C, Guan D, Chen C, He S, Liu X, Wang C, et al. Rapid detection of unconjugated estriol in the serum via superparamagnetic lateral flow immunochromatographic assay. Anal Bioanal Chem. 2018;410(1):123-30. https://doi.org/10.1007/s00216-017-0699-6

8. Cesar JA, Camerini AV, Paulitsch RG, Terlan RJ. Non-performance of serological tests for syphilis during prenatal care: prevalence and associated factors. Rev Bras Epidemiol. 2020;23(E200012):1-12. https://doi.org/10.1590/1980-549720200012

9. Lansky S, Friche AAL, Silva AAM, Campos A. Birth in Brazil survey: neonatal mortality profile, and maternal and child care. Cad Saúde Pública. 2014;30(supl1):S192-S207. https://doi.org/10.1590/0102-311X00133213

10. Ministério da Saúde (BR). Protocolo de investigação de transmissão vertical: 2014 [Internet]. 2018 [cited 2020 Oct 30]. Available from: https://portaldeboaspraticas.iff.fiocruz.br/wp-content/uploads/2020/08/protocolo_de_investigacao_de_transmissao_vertical.pdf

11. Ministério da Saúde (BR). Boletim Epidemiológico de Sífilis - 2018 [Internet]. 2018 [cited 2019 Jun 11]. Available from: http://www.aids.gov. $\mathrm{br} / \mathrm{pt}$-br/pub/2018/boletim-epidemiologico-de-sifilis-2018

12. Saavedra JS, Cesar JA, Linhares AO. Prenatal care in Southern Brazil: coverage, trend and disparities. Rev Saúde Pública. 2019;53(40):1-8. https://doi.org/10.11606/S1518-8787.2019053000968

13. Tsunechiro MA, Lima MOPL, Bonadio IC, Corrêa MD, Silva AVAS, Donato SCT. Prenatal care assessment according to the Prenatal and Birth Humanization Program. Rev Bras Mater Infant. 2018;18(4):771-80. https://doi.org/10.1590/1806-93042018000400006

14. Luz LA, Aquino R, Medina MG. Evaluation of the quality of Prenatal Care in Brazil. Saúde Debate. 2018;42(Esp 2):111-26. https://doi. org/10.1590/0103-11042018s208

15. Vescovi JS, Schuelter-Trevisol F. Increase of incidence of congenital syphilis in Santa Catarina state between 2007-2017: temporal trend analysis. Rev Paul Pediatr. 2020;38(e2018390):1-8. https://doi.org/10.1590/1984-0462/2020/38/2018390

16. Olveira MIC, Silva KS, Gomes DM. Factors associated with submission to HIV rapid test in childbirth care. Ciênc Saúde Coletiva. 2018;23(2):575-84. https://doi.org/10.1590/1413-81232018232.11612016

17. Araújo MAL, Andrade RFV, Barros VL, Bertoncini PMRP. Factors associated with unfavorable outcomes caused by Syphilis infection in pregnancy. Rev Bras Saúde Matern Infant. 2019;19(2):411-9. https://doi.org/10.1590/1806-93042019000200009

18. Caus ECM, Andrade JA. Evaluation of the performance of the quick test in nursing consultation as facing syphilis. Saúde Meio Ambient. 2020; 9(1):106-19. https://doi.org/10.24302/sma.v9i0.2594

19. Holzmann APF, Silva CSO, Soares JAS, Vogt SE, Alves CR, Taminato M, et al. Preventing vertical HIV virus transmission: hospital care assessment. Rev Bras Enferm. 2020;73(3):1-8. https://doi.org/10.1590/0034-7167-2019-0491

20. Nascimento DSF, Silva RC, Tártari DO, Cardoso EK. Report about implementation issues of rapid test for the detection of syphilis in pregnant women in the SUS Primary Care in a city of Southern Brazil. Rev Bras Med Fam Comunidade. 2018;13(40):1-8. https://doi.org/10.5712/ rbmfc13(40)1723

21. Figueiredo DCMM, Figueiredo AM, Souza TKB, Tavares G, Vianna RPT. Relationship between the supply of syphilis diagnosis and treatment in primary care and incidence of gestational and congenital syphilis. Cad Saúde Pública. 2020;36(3):1-12. https://doi. org/10.1590/0102-311X00074519

22. Silva NC, Leite PM, Pereira RMS. ANTI-HIV testing on pregnancy: experience of nursing professionals. Braz J Develop. 2020;6(7):47716-26. https://doi.org/10.34117/bjdv6n7-421 